9-29-2015

\title{
Phylogeographic perspective on the distribution and dispersal of a marine pathogen, the oyster parasite Bonamia exitiosa
}

Kristina M. Hill-Spanik

Virginia Institute of Marine Science

Jan McDowell

Virginia Institute of Marine Science

Kimberly S. Reece

Virginia Institute of Marine Science

Eugene M. Burreson

Virginia Institute of Marine Science

Ryan B. Carnegie

Virginia Institute of Marine Science

Follow this and additional works at: https://scholarworks.wm.edu/vimsarticles

Part of the Marine Biology Commons

\section{Recommended Citation}

Hill-Spanik, Kristina M.; McDowell, Jan; Reece, Kimberly S.; Burreson, Eugene M.; and Carnegie, Ryan B., Phylogeographic perspective on the distribution and dispersal of a marine pathogen, the oyster parasite Bonamia exitiosa (2015). Marine Ecology Progress Series, 536, 65-76.

doi: $10.3354 /$ meps 11425

This Article is brought to you for free and open access by the Virginia Institute of Marine Science at W\&M ScholarWorks. It has been accepted for inclusion in VIMS Articles by an authorized administrator of W\&M ScholarWorks. For more information, please contact scholarworks@wm.edu. 


\title{
Phylogeographic perspective on the distribution and dispersal of a marine pathogen, the oyster parasite Bonamia exitiosa
}

\author{
Kristina M. Hill-Spanik ${ }^{1,2, *}$, Jan R. McDowell ${ }^{1}$, Nancy A. Stokes ${ }^{1}$, \\ Kimberly S. Reece ${ }^{1}$, Eugene M. Burreson ${ }^{1}$, Ryan B. Carnegie ${ }^{1}$ \\ ${ }^{1}$ Virginia Institute of Marine Science, College of William \& Mary, PO Box 1346, Gloucester Point, Virginia 23062, USA \\ ${ }^{2}$ Present address: Grice Marine Laboratory, College of Charleston, 205 Fort Johnson Road, Charleston, South Carolina 29412, USA
}

\begin{abstract}
The significance of infectious disease has intensified as our marine ecosystems are increasingly altered, with molluscan taxa being among the affected. One of the important pathogens to emerge in recent years, the oyster parasite Bonamia exitiosa, has a broad geographic distribution and has been found to infect a number of oyster species. In order to better understand how $B$. exitiosa achieved this wide distribution, a gene genealogy was constructed using internal transcribed spacer region ribosomal DNA sequencing data from across the host species range. The analysis revealed population structure in the form of 4 well-defined groups of sequences: 3 corresponding to geographic regions (temperate Atlantic and Pacific waters of the Southern Hemisphere, California, and the western Atlantic along the coast of the Americas) and the fourth geographically cosmopolitan. Inclusion of B. exitiosa sequences from New Zealand, Australia, and Argentina in the Southern Hemisphere group may reflect natural dispersal of the parasite via rafting with oyster hosts, whereas the California group may reflect limited anthropogenic movement of a host species, Ostrea lurida. The extensive geographic distribution of $B$. exitiosa parasites belonging to the cosmopolitan and Atlantic Coast groups may relate to both natural and anthropogenic dispersal of a single host, $O$. stentina, which is distributed from the eastern Americas to the Mediterranean and African coast to New Zealand - that is, in most regions where B. exitiosa has been found to occur.
\end{abstract}

KEY WORDS: Marine disease $\cdot$ Bonamia $\cdot$ Haplosporidia $\cdot$ Phylogeography $\cdot$ Ostrea stentina Resale or republication not permitted without written consent of the publisher

\section{INTRODUCTION}

Infectious disease has grown in significance in our increasingly impacted and altered marine ecosystems (Harvell et al. 1999), with mollusks being among the affected taxa (Ward and Lafferty 2004). Protozoan parasites in the genus Bonamia (Haplosporidia; Sprague 1979) are one of the major threats to oyster populations, yet we know little about how and when they came to achieve their current distributions. B. exitiosa (Hine et al. 2001, Berthe \& Hine 2003) in particular has caused large-scale mortalities in New Zealand Ostrea chilensis since it was discovered in Foveaux Straight, New Zealand, in the 1980s (Dinamani et al. 1987), with retrospective evidence that it was associated with disease events as early as 1964 (Hine et al. 2001). Since its description, B. exitiosa has been observed in several commercial and non-commercial oyster hosts in various locations around the world (Hill et al. 2014). In addition to $O$. chilensis from New Zealand, it has been noted to infect $O$. angasi and Saccostrea glomerata in Australia; O. puelchana and O. stentina $(=O$. equestris, Shilts et al. 2007) from Argentina; wild O. stentina (= 
O. equestris, Shilts et al. 2007) and experimental Crassostrea ariakensis along the southeastern US coast; $O$. lurida in California, USA $;$. edulis in England, Spain, and Italy; and O. stentina in Tunisia (Kroeck \& Montes 2005, Corbeil et al. 2006, Abollo et al. 2008, Hill et al. 2010, 2014, Narcisi et al. 2010, Longshaw et al. 2013). B. exitiosa also potentially infects $O$. stentina $(=O$. aupouria, Shilts et al. 2007) from New Zealand (based on PCR results only; Hill et al. 2014). It is not yet clear how the disease it causes (known as bonamiasis) impacts some populations, especially with respect to non-commercial hosts. However, because $B$. exitiosa has been the cause of severe mortality in some oyster species in the wild (Doonan et al. 1994, Cranfield et al. 2005) and in aquaculture systems (Burreson et al. 2004), understanding how it came to achieve its wide distribution is important. If the more recent observations of $B$. exitiosa are the result of contemporary introductions rather than long-established presences that have gone unnoticed, it is imperative that preventative measures be taken to obviate similar economic and ecological losses due to accidental introductions elsewhere.

Phylogeographic studies explore the principles and processes involved in the geographical distributions of genealogical lineages, especially those within and among closely related species (Avise 2000). With the rise in global connectivity, these studies are becoming increasingly useful for tracking the concomitant dispersal of organisms around the world. Some $B$. exitiosa dispersal hypotheses have already been proposed, but these have been based mainly on the occurrence of epizootics and/or conjecture about the parasite's supposed presence/absence. For example, $B$. exitiosa purportedly reached Australia from its presumed origins in New Zealand through shipment of live, commercial-sized oysters, which were held in Victorian and Tasmanian waters in the early 1990s (Hine \& Jones 1994, Hine 1996). Additionally, Abollo et al. (2008) detected B. exitiosa in O. edulis in Galicia, NW Spain, and they hypothesized that the parasite could have been inadvertently introduced through the legal or illegal importation of oysters from $B$. exitiosa-endemic areas. The authors also suggested the possibility of an introduction via the ballast water and outer hulls of ships, which was a hypothesis proposed by Bishop et al. (2006) regarding the presence of $B$. exitiosa (then identified only as Bonamia sp.) in North Carolina C. ariakensis and $O$. stentina. We sought to test the validity of existing hypotheses and to develop additional hypotheses regarding the dispersal of $B$. exitiosa using network analysis to examine internal transcribed spacer region ribosomal DNA (ITS rDNA) sequences of $B$. exitiosa found in New Zealand, Australia, Argentina, Tunisia, and along the east and west coasts of the USA.

\section{MATERIALS AND METHODS}

\section{Sample collection and DNA extraction}

Samples of 7 oyster species were obtained from 10 locations (Table 1). Oysters were shucked, and small pieces of gill and mantle tissue $\left(\sim 3-5 \mathrm{~mm}^{3}\right)$ were preserved individually in $95 \%$ ethanol or placed directly in lysis solution (QIAamp DNA Kit, Qiagen), except for the 2004 California Ostrea lurida samples, where 3 to 4 individuals were placed in the same tube and stored at $-80^{\circ} \mathrm{C}$ until being transferred to $100 \%$ ethanol for shipping. Genomic DNA from each oyster sample was extracted using a Qiagen QIAamp DNA Kit. DNA was eluted in 100-225 $\mu \mathrm{l}$ of elution buffer and stored at $4^{\circ} \mathrm{C}$.

\section{PCR, cloning, and sequencing}

PCR, cloning, and sequencing of ITS region rDNA was performed as described by Hill et al. (2014). Briefly, primers HaploITSf (Hill et al. 2010) and ITS-B (= reverse primer $D_{i}$ Goggin 1994) were used to amplify a $\sim 750$ base pair (bp) product, which includes $\sim 220$ bp of the $3^{\prime}$ end of the small subunit ribosomal RNA (SSU rRNA) gene, the complete ITS-1, 5.8S gene, and ITS-2 region rDNA, and a short fragment ( $20 \mathrm{bp}$ ) of large subunit (LSU) rDNA. A $25 \mu \mathrm{l}$ total reaction contained $1 \times$ PCR Buffer (Invitrogen), 2-2.5 mM MgCl $2,0.2 \mathrm{mM}$ dNTPs, each primer at $0.25 \mu \mathrm{M}, 0.05 \mathrm{U} \mathrm{\mu l}^{-1}$ Platinum Taq DNA polymerase (Invitrogen), and 200-250 ng (=0.5-1.6 $\mu \mathrm{l})$ template DNA. A 7 min initial denaturation was followed by 35 cycles of denaturation at $95^{\circ} \mathrm{C}$ for $1 \mathrm{~min}$, annealing between 55 and $61^{\circ} \mathrm{C}$ for $1 \mathrm{~min}$, and extension at $72^{\circ} \mathrm{C}$ for $1.5 \mathrm{~min}$, followed by a final extension at $72^{\circ} \mathrm{C}$ for 7 min.

Purified PCR products were cloned into plasmid vector pCR4-TOPO using the TOPO TA Cloning Kit (Invitrogen), and then transformed into One Shot TOP10 competent Escherichia coli cells (Invitrogen). Bacterial colonies containing plasmid inserts of the appropriate size were cultured and then extracted using the QIAprep Spin Miniprep Kit protocol (Qiagen). Primers HaploITSf (Hill et al. 2010) and ITS-B 


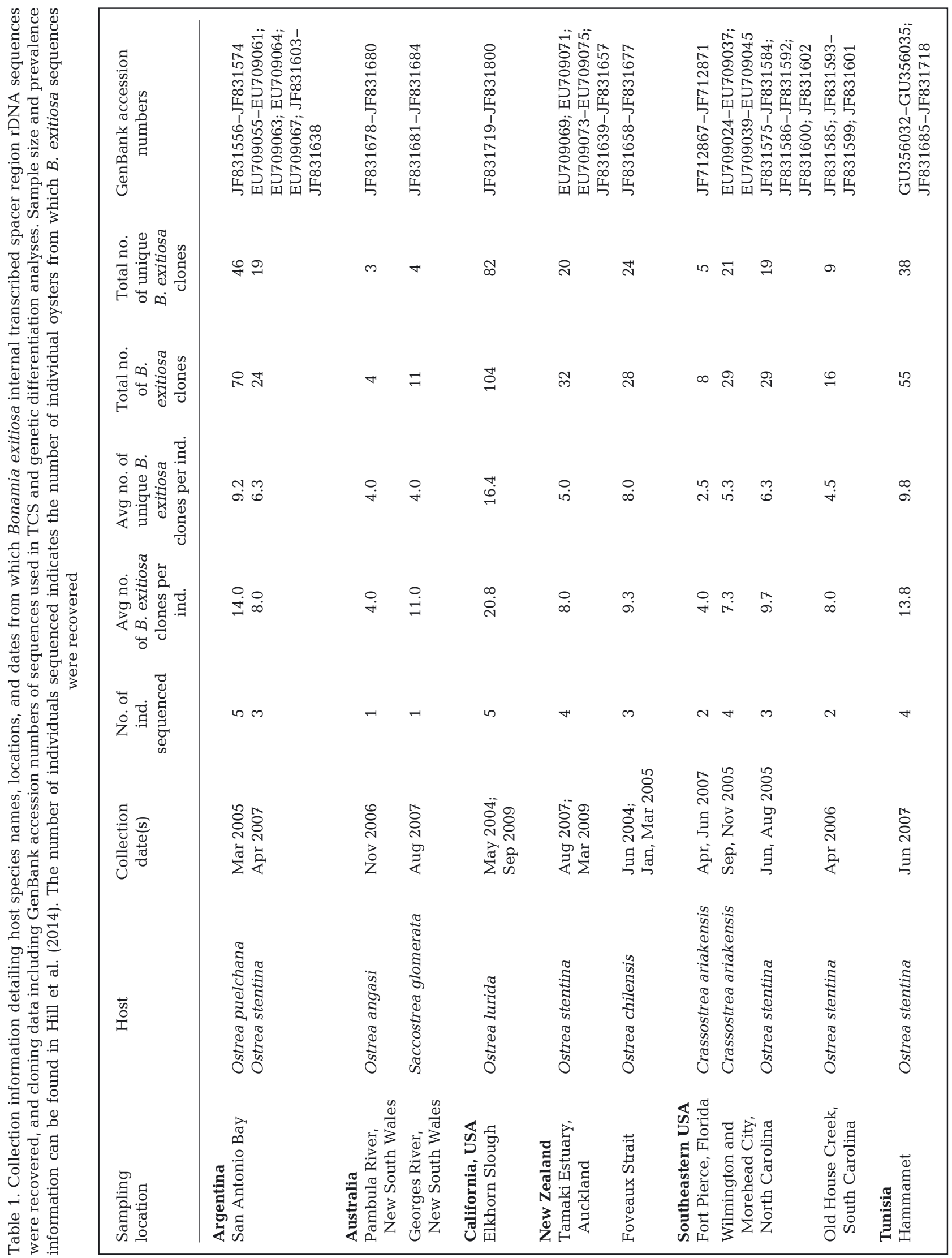


(= reverse primer $D_{i}$ Goggin 1994) were used for bidirectional sequencing, which was performed on either a LI-COR 4200L or a 16-capillary $3130 \mathrm{xl}$ Genetic Analyzer (Applied Biosystems). Complementary sequences were compared to one another and to their chromatograms using MacVector 8.0 (Oxford Molecular) or CodonCode Aligner.

\section{Sequence alignment and network analysis}

Bonamia exitiosa sequences were aligned using MAFFT v. 6 (Katoh \& Toh 2008). When identical $B$. exitiosa sequences were recovered from an individual oyster host, a single representative sequence was used in the alignment since it is not possible to discriminate between the case of multiple $B$. exitiosa parasites with identical sequences and the same $B$. exitiosa clone that is recovered multiple times from the same individual. The GenBank accession numbers of the sequences used are listed in Table 1. Once the alignment was produced, the ends of longer sequences were removed so that, with gaps, the sequences were of equal length.

To examine the genealogical relationships among sequences, the $B$. exitiosa sequence alignment was analyzed using TCS (Clement et al. 2000). Gaps were treated as a fifth state for the network analysis, and the program calculated maximum connection steps at $95 \%$.

\section{Genetic differentiation}

Maximum likelihood fits of 24 different nucleotide substitution models were conducted in MEGA6 (Tamura et al. 2013) and the lowest Bayesian information criterion score was considered to best describe the observed substitution pattern among sequences. Sequences were collapsed into unique haplotypes using FaBox v. 1.41 (Villesen 2007). Population pairwise $\Phi_{\mathrm{ST}}$ values were calculated between geographic collections with and without consideration of $B$. exitiosa sequences recovered from different host species as different groups. To assess the magnitude of differences between groups recovered by the TCS analysis, pairwise $\Phi_{\mathrm{ST}}$ values between groups were calculated. Significance was assessed using 10000 permutations of the data. All $\Phi_{\mathrm{ST}}$ values between sequences were based on a Kimura 2-parameter (K2P) distance method using the Arlequin v. 3.1.5.3 software package (Excoffier \& Lischer 2010). Nucleotide diversity per site $(\pi)$, gene diversity $(h)$, and the average number of pairwise nucleotide differences within and between sequences from different locations and groups $(k)$ were also calculated using the Arlequin software assuming a K2P model. Here, gene diversity $(h)$ is defined as the probability that 2 randomly chosen sequences are different in a population (Nei 1987). Genetic differentiation estimates and tests of population subdivision including both haplotype- and nucleotide-based statistics were calculated using DNAsp (Librado \& Rozas 2009).

\section{RESULTS}

We found 290 Bonamia exitiosa ITS region rDNA sequences from a total of 410 cloned and sequenced PCR fragments ( $720 \mathrm{bp}$ ) recovered from 7 oyster host species after excluding identical sequences recovered from a single oyster. Information regarding the number of individual oysters per geographic region from which $B$. exitiosa sequences were obtained and other information regarding clone number and averages per sampling location and host are presented in Table 1. B. exitiosa sequences were obtained from 1 to 11 oysters per location. The average number of clones sequenced per individual varied from 4.0 to 20.8 , and the average number of unique sequences per individual ranged from 2.5 to 16.4 (Table 1). The total number of clones sequenced per region ranged from 14 (Australia) to 104 (California), with the total number of unique sequences ranging from 7 (Australia) to 82 (California).

Of the $290 \mathrm{~B}$. exitiosa sequences analyzed, 234 unique sequences were present, and 4 well-defined groups emerged and were designated as 'Cosmopolitan,' 'Southern Hemisphere,' 'western Atlantic,' and 'California' based on their geographic distribution (Figs. $1 \& 2$ ). The most common sequence belonged to the Cosmopolitan group and was found at every sampling location where $B$. exitiosa was detected by PCR except in California, and in every oyster host species except Ostrea lurida from California, Saccostrea glomerata from Australia, and O. chilensis from New Zealand. This sequence was found in a total of 23 individuals: 4 O. stentina from Tunisia, 4 $O$. puelchana and $3 O$. stentina from Argentina, $1 O$. stentina from New Zealand, $1 O$. angasi from Australia, and 5 O. stentina and 5 Crassostrea ariakensis from North Carolina, South Carolina, and/or Florida, making up $36.7 \%$ of haplotypes in the Cosmopolitan group. A second sequence (4.4\% of haplotypes) within the Cosmopolitan group was found in 4 individuals: 1 O. stentina from Tunisia, 2 O. puelchana from 


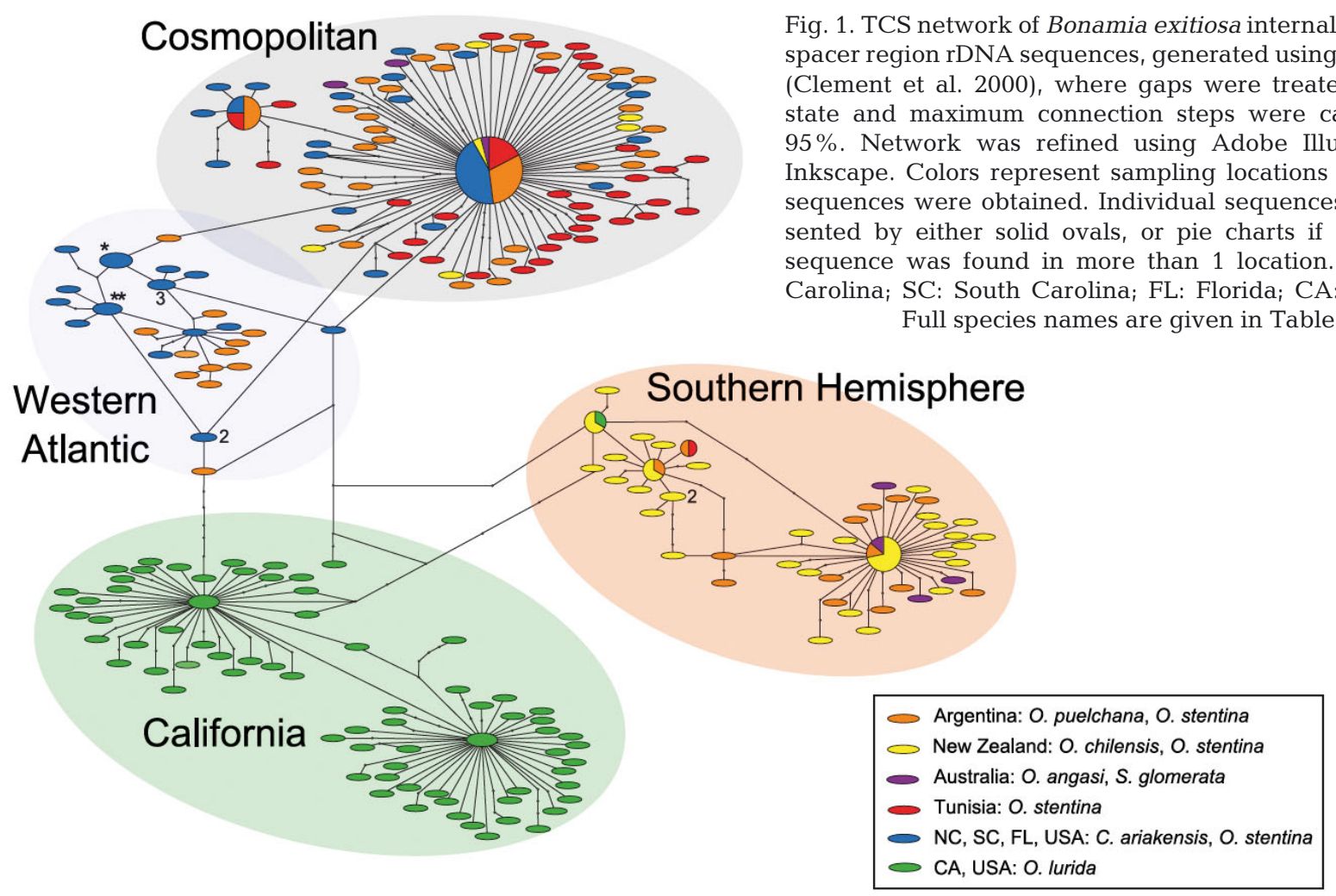

Fig. 1. TCS network of Bonamia exitiosa internal transcribed spacer region rDNA sequences, generated using TCS v. 1.21 (Clement et al. 2000), where gaps were treated as a fifth from which the specific sequence was found in more than 1 location. NC: North Full species names are given in Table 1

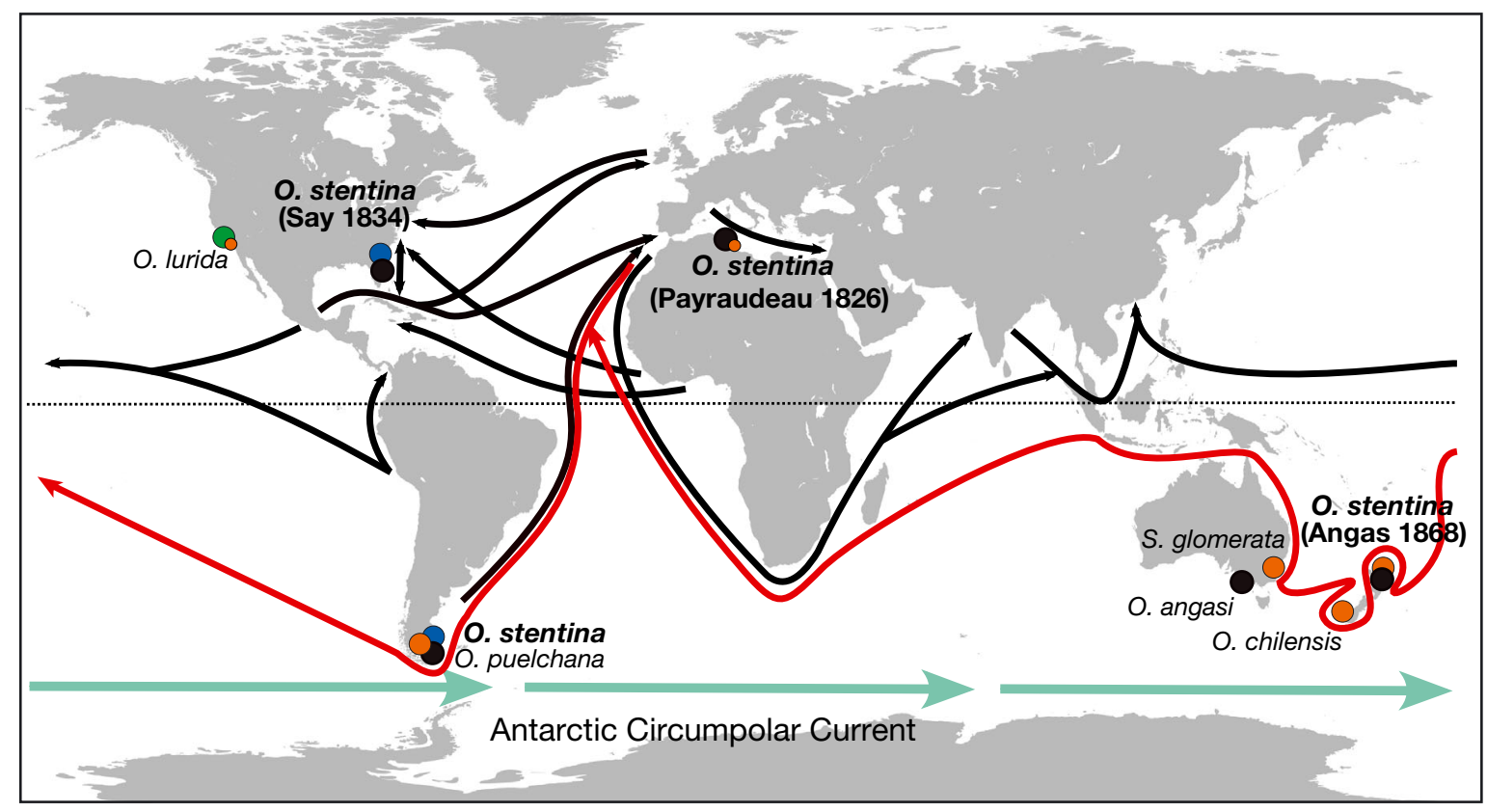

Southern Hemisphere $B$. exitiosa

- California B. exitiosa

- Cosmopolitan B. exitiosa

- Western Atlantic B. exitiosa .......... Equator
Fig. 2. Current geographic distribution of Bonamia exitiosa lineages and host Ostrea stentina, with depictions of proposed dispersal hypotheses: major global trade routes from the 1400s to the 1800s (black arrows; Rodrigue 2013) and an example of 1 voyage (red arrows; Turnbull 2004) out of hundreds made during the Age of Exploration. Of the 2 sizes of orange circles, the smaller depicts finding a Southern Hemisphere $B$. exitiosa outside of its geographic range 
Table 2. Diversity indices of Bonamia exitiosa by sampling location and by TCS analysis results. n: number of sequences analyzed; $h$ : gene diversity; $k$ : average number of pairwise nucleotide differences within and between sequences from different locations and groups; $\pi$ : nucleotide diversity per site

\begin{tabular}{|c|c|c|c|c|c|}
\hline Geographic region & Host(s) & $\mathrm{n}$ & $h$ & $k$ & $\pi$ \\
\hline \multicolumn{6}{|l|}{ Sampling location } \\
\hline Australia & Saccostrea glomerata & 4 & $1.000 \pm 0.177$ & $2.509 \pm 1.690$ & $0.004 \pm 0.003$ \\
\hline Australia & Ostrea angasi & 3 & $1.000 \pm 0.272$ & $4.026 \pm 2.741$ & $0.006 \pm 0.005$ \\
\hline Tunisia & O. stentina & 38 & $0.996 \pm 0.008$ & $3.155 \pm 1.670$ & $0.004 \pm 0.003$ \\
\hline Argentina & O. puelchana & 46 & $0.993 \pm 0.008$ & $3.140 \pm 1.657$ & $0.004 \pm 0.003$ \\
\hline Argentina & O. stentina & 19 & $0.983 \pm 0.026$ & $2.277 \pm 1.307$ & $0.003 \pm 0.002$ \\
\hline New Zealand & O. chilensis & 24 & $0.989 \pm 0.015$ & $1.632 \pm 0.998$ & $0.002 \pm 0.002$ \\
\hline New Zealand & O. stentina & 20 & $0.984 \pm 0.024$ & $2.529 \pm 1.420$ & $0.004 \pm 0.002$ \\
\hline North Carolina & C. ariakensis & 21 & $0.976 \pm 0.023$ & $1.764 \pm 1.064$ & $0.002 \pm 0.002$ \\
\hline North and South Carolina & O. stentina & 28 & $0.950 \pm 0.025$ & $1.645 \pm 0.999$ & $0.002 \pm 0.002$ \\
\hline Florida & Crassostrea ariakensis & 5 & $0.900 \pm 0.161$ & $1.605 \pm 1.131$ & $0.002 \pm 0.002$ \\
\hline California & O. lurida & 82 & $0.994 \pm 0.004$ & $2.660 \pm 1.433$ & $0.004 \pm 0.002$ \\
\hline \multicolumn{6}{|l|}{ TCS grouping } \\
\hline Southern Hemisphere & O. stentina, O. chilensis, O. puelchana, S. glomerata & 57 & $0.983 \pm 0.009$ & $1.923 \pm 1.110$ & $0.003 \pm 0.002$ \\
\hline California & O. lurida & 81 & $0.994 \pm 0.004$ & $2.643 \pm 1.426$ & $0.004 \pm 0.002$ \\
\hline Cosmopolitan & O. stentina, O. puelchana, C. ariakensis, O. angasi & 116 & $0.964 \pm 0.014$ & $2.637 \pm 1.418$ & $0.004 \pm 0.002$ \\
\hline Western Atlantic & O. stentina, C. ariakensis & 36 & $0.960 \pm 0.020$ & $1.600 \pm 0.972$ & $0.002 \pm 0.002$ \\
\hline \multicolumn{6}{|l|}{ TCS Cosmopolitan group } \\
\hline Tunisia & O. stentina & 37 & $0.996 \pm 0.008$ & $3.231 \pm 1.705$ & $0.005 \pm 0.003$ \\
\hline Argentina & O. stentina, O. puelchana & 39 & $0.970 \pm 0.020$ & $2.623 \pm 1.433$ & $0.004 \pm 0.002$ \\
\hline $\begin{array}{l}\text { Western Atlantic } \\
\text { (North \& South Carolina, } \\
\text { Florida, USA) }\end{array}$ & O. stentina, C. ariakensis & 30 & $0.897 \pm 0.053$ & $1.807 \pm 1.072$ & $0.003 \pm 0.002$ \\
\hline Australia/New Zealand & O. stentina, O. angasi & 9 & $0.972 \pm 0.064$ & $2.904 \pm 1.680$ & $0.004 \pm 0.003$ \\
\hline
\end{tabular}

Argentina, and 1 C. ariakensis from North Carolina. All but one $B$. exitiosa sequence from Tunisian $O$. stentina $(97.4 \%)$ belonged to the Cosmopolitan group. Sequences within the Cosmopolitan group $(n=116)$ had a nucleotide sequence diversity of $0.004 \pm 0.002$, a gene diversity of $0.964 \pm 0.014$, and sequences differed by an average of $2.637 \pm 1.418$ nucleotides (Table 2).

The second cluster of sequences, the Southern Hemisphere group, was found almost exclusively in oysters sampled in Argentina, New Zealand, and Australia (96.3\% of Southern Hemisphere sequences were from these 3 sampling locations, Figs. 1 \& 2). Sequences within the Southern Hemisphere group ( $\mathrm{n}=57$ ) had a nucleotide sequence diversity of 0.003 \pm 0.002 , a gene diversity of $0.983 \pm 0.010$, and sequences differed by an average of $1.923 \pm 1.110$ nucleotides (Table 2). The most common sequence in this group, representing $15.2 \%$ of Southern Hemisphere haplotypes, was found in 7 individuals: $1 O$. puelchana from Argentina, $2 \mathrm{O}$. chilensis and $3 \mathrm{O}$. stentina from New Zealand, and 1 S. glomerata from Australia. A second sequence in the Southern Hemisphere group $(6.5 \%$ of Southern Hemisphere haplotypes) was found in 3 individuals: $2 O$. chilensis from New Zealand and 1 O. stentina from Argentina. Southern Hemisphere sequences were also recovered from 2 oysters sampled from outside of this geographic region. One sequence from an $O$. stentina from Tunisia was found to belong to the Southern Hemisphere group and was identical to a sequence found in an $O$. stentina from Argentina. A second Southern Hemisphere sequence was found in $1 O$. lurida from California, and this sequence was identical to 2 sequences recovered from New Zealand, 1 found in O. chilensis and 1 found in O. stentina.

A third cluster of sequences, the western Atlantic group, was predominantly found in samples taken from North Carolina, South Carolina, and Florida; $66.7 \%$ of the western Atlantic group sequences were from these locations. However, several sequences from oysters sampled in Argentina also belonged to this group. Overall, sequences within the western Atlantic group $(\mathrm{n}=36)$ had a nucleotide sequence diversity of $0.002 \pm 0.002$, a gene diversity of $0.960 \pm$ 0.020 , and sequences differed by an average of 1.600 \pm 0.972 (Table 2). The most common western Atlantic group sequence was found only in North and South Carolina (Fig. 1). This sequence, which represented $24 \%$ of haplotypes in this group, was found in 6 indi- 
viduals: 4 O. stentina (3 from North Carolina and 1 from South Carolina) and $2 C$. ariakensis from North Carolina. A second sequence was shared between 2 O. stentina and $2 C$. ariakensis from North Carolina (16\% of haplotypes in this group). A third sequence was found in 2 O. stentina (1 from North Carolina and 1 from South Carolina) and 1 C. ariakensis from North Carolina $(8 \%)$, and a fourth sequence was found in 2 O. stentina: 1 from North Carolina and 1 from South Carolina (8\%). All other sequences were unique. Twelve sequences recovered from oysters sampled in Argentina were found to belong to the western Atlantic group, 9 from $O$. puelchana and 3 from $O$. stentina, comprising $18.5 \%$ of the sequences from Argentina.

The 2 most common sequences in the California group were each found 5 times (each representing $6.8 \%$ of haplotypes in this group) and differed from each other by $1 \mathrm{bp}$ (Fig. 1). These sequences were only found in O. lurida from California. The other sequences belonging to this group were unique. Sequences within the California group $(\mathrm{n}=81)$ had a nucleotide sequence diversity of $0.004 \pm 0.002$, a gene diversity of $0.994 \pm 0.004$, and sequences differed by an average of $2.643 \pm 1.426$ nucleotides (Table 2).

Overall, gene diversity was 0.99 , and there were an average of 7.94 nucleotide differences among the groups. The number of uncorrected average pairwise distances between groups ranged from 1.888 between the Southern Hemisphere and western Atlantic groups and 4.220 between Southern Hemisphere and California groups. Population pairwise $\Phi_{\mathrm{ST}}$ values ranged from 0.043 between the Atlantic Coast and California groups to 0.450 between the Southern Hemisphere and California groups. Estimates of genetic differentiation including both gene- and nucleotide-based estimates indicated that there were significant differences among all groups $(\mathrm{p}<0.001$; Table 3A)

To examine the relationships among geographic regions, sequences were grouped by collection location (without regard to TCS clustering). If $B$. exitiosa was found in multiple host species in a single geographic region, host species were analyzed

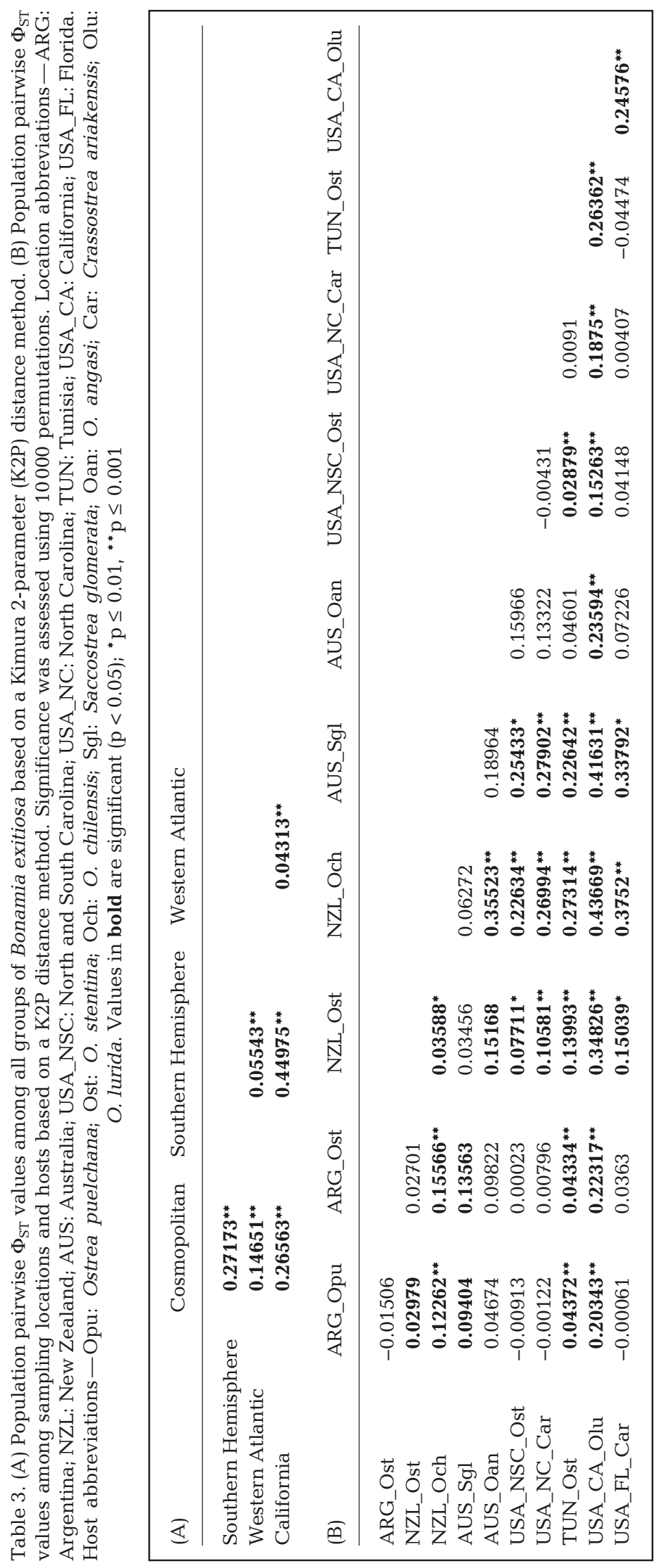


Table 4. Pairwise differences between populations of Bonamia exitiosa based on a Kimura 2-parameter distance method are shown above the diagonal and the corrected average pairwise difference between populations $\left(\pi_{\text {between } x y}-\left(\pi_{\text {within } x}+\pi_{\text {within } y}\right) / 2\right)$ are below the diagonal. Location and host abbreviations as in Table 3

\begin{tabular}{|c|c|c|c|c|c|c|c|c|c|c|c|}
\hline & ARG_Opu & ARG_Ost & NZL_Ost & NZL_Och & AUS_Sgl & AUS_Oan & $\begin{array}{c}\text { USA } \\
\text { NSC_Ost }\end{array}$ & $\begin{array}{c}\text { USA_NC_ } \\
\text { Car }\end{array}$ & TUN_Ost & $\begin{array}{c}\text { USA_ } \\
\text { CA_Olu }\end{array}$ & $\begin{array}{c}\text { USA_FL_ } \\
\text { Car }\end{array}$ \\
\hline ARG_Opu & & 2.702 & 2.961 & 2.793 & 3.254 & 3.634 & 2.402 & 2.489 & 3.321 & 3.639 & 2.534 \\
\hline ARG_Ost & -0.030 & & 2.493 & 2.324 & 2.762 & 3.193 & 1.974 & 2.053 & 2.884 & 3.233 & 2.094 \\
\hline NZL_Ost & 0.100 & 0.068 & & 2.174 & 2.643 & 3.572 & 2.272 & 2.422 & 3.361 & 4.023 & 2.586 \\
\hline NZL_Och & 0.386 & 0.353 & 0.073 & & 2.117 & 3.509 & 2.140 & 2.346 & 3.404 & 4.061 & 2.626 \\
\hline AUS_Sgl & 0.397 & 0.340 & 0.092 & 0.020 & & 3.975 & 2.605 & 2.811 & 3.858 & 4.516 & 3.091 \\
\hline AUS_Oan & 0.012 & 0.007 & 0.257 & 0.646 & 0.663 & & 2.846 & 2.892 & 3.647 & 3.973 & 2.850 \\
\hline USA_NSC_Ost & -0.013 & -0.005 & 0.163 & 0.485 & 0.499 & -0.024 & & 1.714 & 2.507 & 2.610 & 1.719 \\
\hline USA_NC_Car & 0.015 & 0.015 & 0.254 & 0.632 & 0.647 & -0.037 & -0.008 & & 2.524 & 2.812 & 1.723 \\
\hline TUN_Ost & 0.145 & 0.143 & 0.491 & 0.988 & 0.992 & 0.016 & 0.083 & 0.040 & & 3.933 & 2.414 \\
\hline USA_CA_Olu & 0.724 & 0.753 & 1.414 & 1.906 & 1.911 & 0.603 & 0.447 & 0.590 & 1.008 & & 3.095 \\
\hline USA_FL_Car & 0.138 & 0.134 & 0.496 & 0.989 & 1.005 & 0.000 & 0.075 & 0.020 & 0.009 & 0.951 & \\
\hline
\end{tabular}

separately. The highest pairwise $\Phi_{\mathrm{ST}}$ values among geographic regions were between $B$. exitiosa sequences recovered from $O$. lurida from California and $O$. chilensis from New Zealand $(0.437, \mathrm{p}<$ 0.001 , Table 3B); these sequences differed by an uncorrected average of $4.1 \mathrm{bp}$ among sequences from the 2 locations (Table 4). Within a collection location, significant differences were seen between $B$. exitiosa from $O$. stentina and $O$. chilensis in New Zealand $\left(\Phi_{\mathrm{ST}}=0.036, \mathrm{p}=0.005\right)$, and these sequences differed by an average of $2.2 \mathrm{bp}$. Significant differences were also observed between parasite sequences collected from $O$. angasi and $S$. glomerata collected in Australia $\left(\Phi_{\mathrm{ST}}=0.190, \mathrm{p}=\right.$ 0.027 ). Sequences taken from these 2 hosts differed by an average of $4.0 \mathrm{bp}$; however, the overall number of sequences examined was small $(n=7)$. There were no significant differences between $B$. exitiosa sequences sampled from $O$. puelchana and $O$. stentina collected in Argentina or between $O$. stentina and $C$. ariakensis collected in North and South Carolina nor between either Carolina oyster and $C$. ariakensis collected in Florida.

Since the Cosmopolitan group was distributed among all sampling locations, with the exception of California, patterns of diversity among locations within this group were examined separately. Cosmopolitan $B$. exitiosa sequences from Tunisia were the most diverse, having the highest gene diversity $(0.996 \pm 0.008)$, nucleotide diversity $(0.005 \pm 0.003)$, and number of pairwise differences among sequences $(3.231 \pm 1.705)$. The lowest values of all measures within this group occurred in sequences recovered from North and South Carolina and Florida (Table 2).

\section{DISCUSSION}

The analyses in this study revealed that Bonamia exitiosa has a significant level of population structure based on ITS region rDNA sequences, demonstrating that while some sequences are distributed broadly, others appear to be confined to particular geographic areas. The network displays a strong geographic signal in the distribution of $B$. exitiosa sequences, and these differences are statistically significant. Samples comprise 4 reasonably well-defined groups: (1) the Cosmopolitan group, which represents $B$. exitiosa sequences from almost all sampling locations except California; (2) the western Atlantic group, which represents sequences from North and South Carolina, Florida, and Argentina; (3) the Southern Hemisphere group, which is composed mostly of sequences from Argentina, New Zealand, and Australia, with the exception of a sequence from California and another from Tunisia; and (4) the California group, which only includes sequences found in California. These phylogeographic groupings likely indicate that natural historical factors at least partly shaped the current distribution of $B$. exitiosa. However, contemporary anthropogenic factors (e.g. intentional and unintentional introduction or transplantation of oysters for aquaculture or fisheries restoration, or via ship hulls or ballast) also seem to be influencing its distribution as seen with the wide distribution of Cosmopolitan group sequences and the occasional detection of Southern Hemisphere B. exitiosa sequences in northern locations (Tunisia and California).

The predominant cell form of $B$. exitiosa in host tissue is a naked, uninucleate microcell less than $5 \mu \mathrm{m}$ in size, and it is unknown what form the parasite takes 
when released from the host and into the environment. The duration of $B$. exitiosa survival outside of the host is unknown, but Arzul et al. (2009) found that purified B. ostreae cells from host tissue had a clear preference for specific environmental conditions such as temperature $\left(<25^{\circ} \mathrm{C}\right)$ and salinity (euhaline), and further demonstrated that the percentage of $B$. ostreae cells producing esterase activity (a measure of cell viability) decreased significantly at most salinities after $48 \mathrm{~h}$ in suspension (Arzul et al. 2009). B. perspora Carnegie et al. 2006 is currently the only Bonamia species for which spores have been observed. This finding could suggest that other species within the genus also produce these more resistant life-stages (Carnegie et al. 2006) and support the hypothesis of dispersal via ballast water and/or along oceanic currents. However, having not observed these stages in $B$. exitiosa, it seems unlikely that the parasite could disperse great distances through varied environments on its own, suggesting that natural and/or anthropogenic co-dispersal of the parasite and host(s) appears most likely. Based on the geographic patterns resulting from the TCS network analysis, as well as the diversity of the sequences at each location, we discuss potential distribution hypotheses of $B$. exitiosa.

\section{Southern Hemisphere Bonamia exitiosa}

Some $B$. exitiosa sequences seem to be restricted to the Southern Hemisphere, with grouping of sequences from Argentina, northern and southern New Zealand, and Australia, with 2 exceptions: 1 sequence from Tunisia that is identical to a sequence found in Argentina in the same oyster host, O. stentina, and another sequence from California that is identical to a sequence found in both northern and southern New Zealand in 3 different oyster hosts $(O$. lurida, $O$. stentina, and $O$. chilensis, respectively). These sequences are clearly nested within the Southern Hemisphere group, potentially indicating a more recent introduction of the Southern Hemisphere $B$. exitiosa to California and Tunisia. Because of the geographic disjunction of these sequences, anthropogenic means likely facilitated the dispersal of these exceptions.

Although $B$. exitiosa sequences found in New Zealand were predominantly in this group, sequences from northern New Zealand $O$. stentina belonged to both the Southern Hemisphere and Cosmopolitan groups while sequences from southern New Zealand $O$. chilensis exclusively belonged to the Southern Hemisphere group. Consequently, there were signif- icant differences between these 2 sampling areas. Sampling location and host, therefore, influences the geographic patterns we see, highlighting the importance of exploring more locations and hosts. Oysters have been intentionally transplanted to novel locations worldwide since Roman times (Andrews 1980), resulting in the introduction of pathogens to new locales and to naïve, native hosts (Bishop et al. 2006). Crassostrea gigas was introduced to northwestern New Zealand in 1958 from Japan or Tasmania, Australia (Ruesink et al. 2005), and is hypothesized to be a reservoir for B. exitiosa (Lynch et al. 2010). Perhaps this is when the Cosmopolitan $B$. exitiosa was introduced to northern New Zealand. However, until $B$. exitiosa ITS region rDNA sequences from $C$. gigas and other locations in New Zealand are obtained, we cannot speculate further.

With respect to all other sequences found in the Southern Hemisphere group, it appears that gene flow is occurring between New Zealand, Australian, and Argentinean populations of $B$. exitiosa. One likely natural mechanism is rafting of $B$. exitiosainfected oysters on surface currents, such as the Antarctic Circumpolar Current, which has been suggested as a dispersal mechanism for $O$. chilensis from New Zealand to Chile (Ó Foighil et al. 1999, Donald et al. 2005). Providing a means of transport for the host would also conceivably allow transport of the parasite $B$. exitiosa. To further validate this hypothesis, additional samples from Chile and from the African coasts would need to be examined.

\section{California Bonamia exitiosa}

Seventy-one $B$. exitiosa sequences found in $O$. lurida from California were unique to this sampling location and host, with the exception of the single sequence which clustered with the Southern Hemisphere (Figs. 1 \& 2). Other than the possible recent introduction of the Southern Hemisphere B. exitiosa into California, it appears that there is and has been little connectivity between California $B$. exitiosa populations and those of other regions. Based on gene diversity ( $h=0.99$ ) and the structure of the network, the recent introduction of a majority of $B$. exitiosa to California is unlikely. A recent introduction would likely show a network dominated by a single sequence that was very closely related or identical to sequences from the geographic area from which it was introduced rather than the patterns observed in this study.

Restricted dispersal of this particular B. exitiosa lineage could be a result of both natural and anthro- 
pogenic influences. Historically, O. lurida ranged from Baja California (Mexico) to Sitka, Alaska (USA) (Dall 1914), which would define the natural range of this $B$. exitiosa group if it is in fact host specific, and there is currently limited anthropogenic movement of this severely depleted oyster species. Additionally, the East Pacific Barrier, which is 5400 to $7300 \mathrm{~km}$ of uninterrupted open water (Grigg \& Hey 1992), could also prevent the natural dispersal via rafting of both host and parasite, as has been demonstrated for other fauna (Grigg \& Hey 1992).

The introduction of $B$. exitiosa into this region was likely facilitated by anthropogenic means. In Elkhorn Slough, California, alone, 38 of 58 known marine invasive species were likely introduced through oyster culture (Wasson et al. 2001). Based on the number of pairwise differences and pairwise $\Phi_{\mathrm{ST}}$ values in this dataset, the California group appears to be most closely related to the western Atlantic group, suggesting that the California $B$. exitiosa may have originated from the western Atlantic coast (or vice versa). However, it would also be important to explore other regions and hosts. Again, C. gigas, one of the most cosmopolitan macroscopic marine invertebrates, was introduced to the US West Coast in 1902 (Ruesink et al. 2005) and should be considered in future efforts to better understand its potential role in the dispersal of $B$. exitiosa.

\section{Cosmopolitan and western Atlantic Bonamia exitiosa}

The Cosmopolitan group represents sequences found in all sampling locations except in California. This group may represent dispersal over some unknown time period of a lineage particularly adaptable to new hosts and environments, or it may reflect recent and extensive anthropogenic dispersal. Mechanisms of distribution probably vary, but anthropogenic means seem most likely given the disjunct geographic distribution of these samples. The analysis of $B$. exitiosa ITS region rDNA also reveals a more loosely defined cluster of sequences that are closely related to the Cosmopolitan group, but appear to be restricted to the western Atlantic coast (North Carolina, South Carolina, Florida, and even Argentina), found in wild O. puelchana and O. stentina, and experimental Crassostrea ariakensis.

One host that appears to be present in all locations, except California, is $O$. stentina. A phylogenetic study of Ostrea species found O. stentina, O. equestris, and $O$. aupouria to be synonymous (Shilts et al.
2007). All are known hosts of B. exitiosa (Hill et al. 2014), and occur in nearly every geographic region from which $B$. exitiosa has been detected: New Zealand/Australia, the southeastern USA, and the Mediterranean Sea. Each of the oyster species synonymized by Shilts et al. (2007) was described in the 1800s: O. stentina in 1826, O. equestris in 1834, and O. aupouria (= Ostreola virescens) in 1868 (Cook 2010). Thus, this oyster species has been established in its various locales for a minimum of $142 \mathrm{yr}$, making it possible for $B$. exitiosa to have been established for at least this long. Therefore, introduction via natural or anthropogenic means in recent decades cannot fully explain the distribution of this single host and this parasite.

Furthermore, the diversity of $B$. exitiosa ITS region rDNA sequences seen in North Carolina, South Carolina, and Florida is indicative of a non-recent introduction and/or multiple introductions. The former contradicts the hypothesis proposed by Bishop et al. (2006) that recent anthropogenic dispersal via ballast water may explain how $B$. exitiosa came to be in North Carolina. Without a molecular clock and additional genetic data of the hosts themselves, it is difficult to say exactly when this distribution occurred. However, it is plausible that ships during the Age of Exploration (ca. 1400-1800s) colonized by a small oyster, such as $O$. stentina, could have provided transport of $B$. exitiosa.

Natural dispersal of the parasite also may be occurring in the populations of the western Atlantic coast. If a continuous host population exists, it is possible that the western Atlantic coast B. exitiosa is dispersing through direct transmission. With oyster populations in close proximity, hydrodynamics and topographical features may also affect the distribution of the parasite through the water column (Cranfield et al. 2005). Natural co-dispersal with a host or hosts is also a possibility given the geographical proximity of the populations.

O. stentina has not been reported from California, so the presence of $B$. exitiosa may reflect a limited invasion event. Perhaps B. exitiosa-infected O. stentina were introduced transmitting the parasite to the native oyster, $O$. lurida, but did not establish populations. Alternatively, O. stentina may be present cryptically.

\section{Origins of Bonamia exitiosa}

With increasing observations of $B$. exitiosa around the world, the geographic origin of the parasite is 
becoming less clear. Because $B$. exitiosa is present in archival histological material of $O$. chilensis from Foveaux Strait, New Zealand, dating to 1964 (Hine \& Jones 1994), it was hypothesized that the parasite is enzootic to this region (Hine 1996, Corbeil et al. 2006). However, only the Southern Hemisphere $B$. exitiosa was found in this host, and this group is not as diverse as the Cosmopolitan group based on our dataset. The highest diversity was observed in $B$. exitiosa found in Tunisian O. stentina, suggesting a Mediterranean origin. On the other hand, Bonamia spp. SSU rDNA phylogenies have a basal Bonamia sp. in Hawaii (Hill et al. 2014), suggesting an origin at lower latitudes. Exploration of more tropical locations from additional non-commercial host species may provide further insight to the derivation of $B$. exitiosa.

\section{FUTURE WORK}

To better understand how Bonamia exitiosa came to achieve its current distribution, it is essential to understand how its hosts were distributed. The distribution of hosts, particularly the widely distributed host Ostrea stentina, has heavily influenced the dispersal and current biogeographic patterns of the parasite. It is obvious based on this dataset that $B$. exitiosa has a complex history that includes many introductions, both recent and historical. These findings emphasize the need for additional sampling to fill in geographic gaps (e.g. Africa, Asia, and Europe; Abollo et al. 2008, Narcisi et al. 2010, Longshaw et al. 2013) as well as additional potential hosts (e.g. Crassostrea gigas). Additional sampling would also allow calculation of more accurate distance estimates, further resolve the relationships among sampling areas, and perhaps find other evidence of recent dispersal of the parasite.

These hypotheses should further be tested by developing multiple genetic loci of oyster hosts and $B$. exitiosa, as well as the development of a molecular clock. This would further elucidate phylogeographic patterns and dispersal timing of the various hosts and the parasite and perhaps lead to insight into the question of origin.

Acknowledgements. The NOAA Chesapeake Bay Office and Virginia Sea Grant provided support for the characterization of Bonamia exitiosa from the southeastern USA. We thank Stephen Webb and Rodney Roberts (Cawthron Institute, New Zealand), Mike Hine (Fouras, France), Marina Kroeck (Instituto de Biología Marina y Pesquera 'Alte Storni', Argentina), James Moore (Bodega Marine Laboratory, California, USA), Allen Fraser (New Zealand Ministry of Fisheries), Wilma Blom and Gordon Nicholson (Auckland War Memorial Museum, New Zealand), Margaret Morley (Auckland Museum, New Zealand), Susan Laramore and John Scarpa (Harbor Branch Oceanographic Institute, Florida, USA), Loren Coen (South Carolina Department of Natural Resources), and Nejla Bejaoui (Institut National Agronomique de Tunisie, Tunisia) for their assistance with acquisition of samples. Emmett Duffy provided helpful comments on an early version of the text. This is VIMS Contribution number 3498.

\section{LITERATURE CITED}

Abollo E, Ramilo A, Casas SM, Comesana P, Cao A, Carballal MJ, Villalba A (2008) First detection of the protozoan parasite Bonamia exitiosa (Haplosporidia) infecting flat oyster Ostrea edulis grown in European waters. Aquaculture 274:201-207

Andrews (1980) A review of introductions of exotic oysters and biological planning for new importations. Mar Fish Rev 42:1-11

> Arzul I, Gagnaire B, Bond C, Chollet B and others (2009) Effects of temperature and salinity on the survival of Bonamia ostreae, a parasite infecting flat oysters Ostrea edulis. Dis Aquat Org 85:67-75

Avise JC (2000) Phylogeography: the history and formation of species. Harvard University Press, Cambridge, MA

Berthe FCJ, Hine PM (2003) Bonamia exitiosa Hine et al., 2001 is proposed instead of $B$. exitiosus as the valid name of Bonamia sp. infecting flat oysters Ostrea chilensis in New Zealand. Dis Aquat Org 57:181

> Bishop MJ, Carnegie RB, Stokes NA, Peterson CH, Burreson EM (2006) Complications of a non-native oyster introduction: facilitation of a local parasite. Mar Ecol Prog Ser 325:145-152

Burreson EM, Stokes NA, Carnegie RB, Bishop MJ (2004) Bonamia sp. (Haplosporidia) found in nonnative oysters Crassostrea ariakensis in Bogue Sound, North Carolina. J Aquat Anim Health 16:1-9

Carnegie RB, Burreson EM, Hine PM, Stokes NA, Audemard C, Bishop MJ, Peterson CH (2006) Bonamia perspora n. sp. (Haplosporidia), a parasite of the oyster Ostreola equestris, is the first Bonamia species known to produce spores. J Eukaryot Microbiol 53:232-245

- Clement M, Posada D, Crandall K (2000) TCS: a computer program to estimate gene genealogies. Mol Ecol 9: $1657-1659$

Cook S (2010) Bivalvia. In: Cook S (ed) New Zealand marine coastal invertebrates. Canterbury University Press, Christchurch, p 471-541

> Corbeil S, Arzul I, Robert M, Berthe FCJ, Besnard-Cochennec N, Crane MS (2006) Molecular characterisation of an Australian isolate of Bonamia exitiosa. Dis Aquat Org 71: 81-85

> Cranfield HJ, Dunn A, Doonan IJ, Michael KP (2005) Bonamia exitiosa epizootic in Ostrea chilensis from Foveaux Strait, southern New Zealand between 1986 and 1992. ICES J Mar Sci 62:3-13

Dall WH (1914) Notes on West American oysters. Nautilus 28:1-3

Dinamani P, Hine PM, Jones JB (1987) Occurrence and characteristics of the haemocyte parasite Bonamia sp. in the New Zealand dredge oyster Tiostrea lutaria. Dis Aquat Org 3:37-44 
Donald KM, Kennedy M, Spencer H (2005) Cladogenesis as the result of long-distance rafting events in South Pacific topshells (Gastropoda, Trochidae). Evolution 59: 1701-1711

Doonan I, Cranfield H, Michael K (1994) Catastrophic reduction of the oyster, Tiostrea chilensis (Bivalvia, Ostreidae), in Foveaux Strait, New Zealand, due to infestation by the protistan Bonamia sp. NZ J Mar Freshw Res 28: 335-344

- Excoffier L, Lischer HEL (2010) Arlequin suite ver 3.5: a new series of programs to perform population genetics analyses under Linux and Windows. Mol Ecol Resour 10: 564-567

Goggin CL (1994) Variation in the two internal transcribed spacers and 5.8S ribosomal RNA from five isolates of the marine parasite Perkinsus (Protista, Apicomplexa). Mol Biochem Parasitol 65:179-182

Grigg RW, Hey R (1992) Paleoceanography of the Tropical Eastern Pacific Ocean. Science 255:172-178

> Harvell CD, Kim K, Burkholder JM, Colwell RR and others (1999) Emerging marine diseases - climate links and anthropogenic factors. Science 285:1505-1510

Hill KM, Carnegie RB, Aloui-Bejaoui N, Gharsalli RE, White DM, Stokes NA, Burreson EM (2010) Observation of a Bonamia sp. infecting the oyster Ostrea stentina in Tunisia, and a consideration of its phylogenetic affinities. J Invertebr Pathol 103:179-185

- Hill KM, Stokes NA, Webb SC, Hine PM and others (2014) Phylogenetics of Bonamia parasites based on small subunit and internal transcribed spacer region ribosomal DNA sequence data. Dis Aquat Org 110:33-54

Hine PM (1996) The ecology of Bonamia and decline of bivalve molluscs. NZ J Ecol 20:109-116

Hine PM, Jones JB (1994) Bonamia and other aquatic parasites of importance to New Zealand. NZ J Zool 21:49-56

- Hine PM, Cochennec-Laureau N, Berthe FCJ (2001) Bonamia exitiosus n. sp. (Haplosporidia) infecting flat oysters Ostrea chilensis in New Zealand. Dis Aquat Org 47: 63-72

Katoh K, Toh H (2008) Recent developments in the MAFFT multiple sequence alignment program. Brief Bioinform 9: 286-298

Kroeck MA, Montes J (2005) Occurrence of the haemocyte parasite Bonamia sp. in flat oysters Ostrea puelchana farmed in San Antonio Bay (Argentina). Dis Aquat Org 63:231-235

Librado P, Rozas J (2009) DnaSP v5: a software for compre-

Editorial responsibility: Per Palsbøll,

Groningen, The Netherlands hensive analysis of DNA polymorphism data. Bioinformatics 25:1451-1452

Longshaw M, Stone DM, Wood G, Green MJ, White P (2013) Detection of Bonamia exitiosa (Haplosporidia) in European flat oysters Ostrea edulis cultivated in mainland Britain. Dis Aquat Org 106:173-179

Lynch SA, Abollo E, Ramilo A, Cao A, Culloty SC, Villalba A (2010) Observations raise the question if the Pacific oyster, Crassostrea gigas, can act as either a carrier or a reservoir for Bonamia ostreae or Bonamia exitiosa. Parasitology 137:1515-1526

> Narcisi V, Arzul I, Cargini D, Mosca F and others (2010) Detection of Bonamia ostreae and B. exitiosa (Haplosporidia) in Ostrea edulis from the Adriatic Sea (Italy). Dis Aquat Org 89:79-85

Nei M (1987) Molecular evolutionary genetics. Columbia University Press, New York, NY

> Ó Foighil D, Marshall BA, Hilbish TJ, Pino MA (1999) TransPacific range extension by rafting is inferred for the flat oyster Ostrea chilensis. Biol Bull (Woods Hole) 196:122-126

Rodrigue J (2013) The geography of transport systems. Routledge, New York, NY

> Ruesink JL, Lenihan HS, Trimble AC, Heiman KW, Micheli F, Byers JE, Kay MC (2005) Introduction of non-native oysters: ecosystem effects and restoration implications. Annu Rev Ecol Evol Syst 36:643-689

> Shilts MH, Pascual MS, Ó Foighil D (2007) Systematic, taxonomic and biogeographic relationships of Argentine flat oysters. Mol Phylogenet Evol 44:467-473

Sprague V (1979) Classification of the Haplosporidia. Mar Fish Rev 41:40-44

Tamura K, Stecher G, Peterson D, Filipski A, Kumar S (2013) MEGA6: Molecular Evolutionary Genetics Analysis Version 6.0. Mol Biol Evol 30:2725-2729

Turnbull P (2004) Voyaging maps. In South Seas: voyaging and cross-cultural encounters in the Pacific (1760-1800) (p 17680727, map 1). Available at http://southseas.nla. gov.au (accessed on 4 August 2014)

Villesen P (2007) FaBox: an online toolbox for fasta sequences. Mol Ecol Notes 7:965-968

Ward JR, Lafferty KD (2004) The elusive baseline of marine disease: Are diseases in ocean ecosystems increasing? PLoS Biol 2:0542-0547

Wasson K, Zabin CJ, Bediger L, Diaz CM, Pearse JS (2001) Biological invasions of estuaries without international shipping: the importance of intraregional transport. Biol Conserv 102:143-153

Submitted: November 24, 2014; Accepted: July 15, 2015

Proofs received from author(s): September 15, 2015 